\title{
THE GEO-REFERENCED XIX CENTURY CARTOGRAPHY: AN ANALYSIS TOOL AND A PROJECT REFERENCE FOR THE PRESERVATION AND MANAGEMENT OF BUILT AND LANDSCAPE HERITAGE.
}

\author{
A. Cazzani ${ }^{1 *}$, R. Brumana ${ }^{2}$, C.M. Zerbi ${ }^{3}$ \\ ${ }^{1}$ DASTU - Dipartimento di Architettura e Studi Urbani (Department of Architecture and Urban Studies), \\ Politecnico di Milano, Italy - alberta.cazzani@polimi.it \\ ${ }^{2}$ DABC - Dipartimento di Architettura, Ingegneria delle costruzioni e Ambiente costruito (Department of Architecture, \\ Built environment and Construction engineering), Politecnico di Milano, Italy - raffaella.brumana@ polimi.it \\ ${ }^{3} \mathrm{PhD}$ architect freelance, Studio Lunigiana15, Milan, and DASTU - Dipartimento di Architettura e Studi Urbani \\ (Department of Architecture and Urban Studies), Politecnico di Milano, Italy - c.zerbi@lunigiana15.it
}

\section{Commission VI, WG VI/4}

KEY WORDS: Preservation, Built heritage, Historic landscape, Innovative map tools, GEOPAN ATL@S APP, Permanencies, Transformations

\begin{abstract}
:
Considering built and landscape heritage, the paper demonstrates how it is necessary to conserve the historic stratification and to define new compatible plans and uses, identifying the ways to mitigate alteration impacts, requalify degraded areas, enhance natural, historic and cultural values, improve documentary and educational options, and manage new tasks and opportunities. Particularly, the historic complexity of built and landscape heritage, and the level of permanence can be recognized and evaluated by comparing multi-temporal historic and current maps, and surveying the present situation in order to define preservation strategies.

Innovative tools (open source map registry, open source GIS data management) support the critical analysis of the maps, the representation of historic stratification, the evaluation of conservation levels, and the definition of heritage reuse and management. Moreover, innovative applications based on advanced Virtual Hub, when used to publish historical maps as Open Data (GEOPAN ATL@S APP), allow a larger public of non-expert users (tourists, citizens, bikers, students, etc.) to access the extraordinary richness of the historical map contents, and navigate across urban landscapes. Such APPs are thus becoming instruments of awareness with a strong pro-active capacity to stimulate new design plans encompassing local cultural identity and rediscovering traces of the past. ${ }^{1}$
\end{abstract}

\section{INTRODUCTION}

The concept of monument - as it is well known - has largely expanded during the 20th Century: from including few exceptional items of extraordinary value to built heritage, comprising "minor" works alongside sites of significant architectural and artistic importance, as historical and cultural documents of our past. Because of such new perspective of the value of the past, the preservation domain is being enlarged by a radical increase in the types of artefact considered worthy of protection and conservation. In addition to monumental highstyle architecture - the traditional object of preservation - whole new categories of sites are now recognized as equally meritorious: cultural and natural landscapes, historic towns and villages, vernacular buildings and sites, industrial heritage, etc. It should also be remembered that seventy years ago the concept of landscape referred to the aesthetic perception of "Natural Beauty". Today, this definition expanded to include human activities, so landscape now means "an area as perceived by people, whose character is the result of the action and interaction of natural and/or human factors" (European Landscape Convention, 2000).
The most important monuments and historic centers are connected with architectures and cultural sites, parks and gardens, road systems, hydrographic features, agricultural settlements and natural/scenic areas. Natural and cultural features must be analyzed to manage, valorize and rehabilitate outstanding and ordinary landscapes in their dynamic changing. Considering the fact that our tangible and intangible heritage also involves social and economical aspects, in 2011 UNESCO adopted the Recommendation defining the "Historic Urban Landscape" as "the urban area understood as the result of a historic layering of cultural and natural values and attributes, extending beyond the notion of 'historic centre' or 'ensemble' to include the broader urban context and its geographical setting. This wider context notably includes the site's topography, geomorphology, hydrology and natural features, its built environment, both historic and contemporary, its infrastructures above and below ground, its open spaces and gardens, its land use patterns and spatial organisation, perceptions and visual relationships, as well as all other elements of the urban structure. It also includes social and cultural practices and values, economic processes and the intangible dimensions of heritage as related to diversity and

\footnotetext{
* Corresponding author

${ }^{1}$ The present work was conceived and written jointly by the three authors. In particular, Alberta Cazzani developed section 3, Raffaella Brumana developed section 4 and Carlotta Maria Zerbi developed section 2. The authors collaborated in the writing of the Abstract, Introduction and Conclusions, and for the final revision of the manuscript.
} 
identity” (Pereira Roders et al., 2019 and Sonkoli, 2017).

It is thus evident that, in order to set up a preservation and/or a design project, it is necessary to know the stratification of our heritage, not only the historical and constructive characters, but also the uses and users that followed one another in time. In this regard, the analysis of historical maps and the comparison with the current state are a significant method to recognize the degree of conservation or transformation of the land, and to define management and re-use criteria.

This paper specifically considers the case study of the Royal Park of Monza and its context within the Milan metropolitan area, as addressed during a multidisciplinary Preservation Studio course providing geomatics, topography, preservation and conservation knowledge (Laurea Magistrale degree in Architecture, Politecnico di Milano) $)^{2}$. It demonstrates the methodological usefulness of one specific $19^{\text {th }}$ Century historic map (also digitalized), the "Carta Topografica dei Contorni di Milano riconosciuta sul terreno e in parte rilevata e disegnata nella proporzionale scala di 1 a 25.000 dall'I.R. Primo Ingegnere Geografo Pensionato Giovanni Brenna"(i.e. Topographic map of Milan surroundings recognised on the ground and partially measured and drawn in the proportional scale of 1:25.000 by the I.R. First Engineer Geographer Pensioner Giovanni Brenna), usually known as Giovanni Brenna's Map.

Comparing in a comprehensive way - thanks also to innovative tools (open source map registry, open source GIS data management) - the digitalized version of Brenna's map with other historic maps, the current ones, and a direct survey, makes it possible to recognize a lot of landscape features and historical components. It is also possible to evaluate their level of conservation, transformation and maintenance, estimate at different scales the strengths, weaknesses, opportunities and threats (SWOT analysis), and develop a master plan focused on conserving the historic stratification of the architectural and landscape heritage, discovering and valorizing the traces of the past, by defining compatible reuses for today's needs and users.

\section{THE GEO-REFERENCED GIOVANNI BRENNA'S MAP: A TOOL TO READ AND ANALYZE BUILT AND LANDSCAPE HERITAGE}

Detailed $19^{\text {th }}$ Century maps represent an important resource to read and understand the built and landscape heritage.

In particular, cadastral maps and military maps document many historic architectural and landscape components, and also functions and users, enabling a deeper understanding of the complexity of our heritage.

Specifically, aforementioned Giovanni Brenna's map, which was designed by the Lombard cartographer Giovanni Brenna in the mid- $19^{\text {th }}$ Century, is a fundamental document for studying the landscape history in the area of Brianza and North of Milan (Figure 1). The value and usefulness of this map are enhanced by the fact that it was recently georeferenced ${ }^{3}$.

\footnotetext{
2 The Architectural Preservation Studio (Prof. Alberta Cazzani and Prof. Raffaella Brumana, with Arch. Carlotta Maria Zerbi PhD, Arch. Sara Caspani and Arch. Anna Turrina) consists of a Preservation course and a Survey Advanced Technique course.

${ }^{3}$ The map was georeferenced by GIcarus Lab. of Politecnico di MilanoDABC. in the WGS 84 Web Mercator projection (EPSG:3857). Since the main aim for map georeferencing was its online publication, the spherical form of the Web Mercator projection, due to its simplicity in the calculation, allowed saving many computation cycles and enhance web visualization. The georeferencing was carried out using Ground Control Points measured using OpenStreetMap.
}

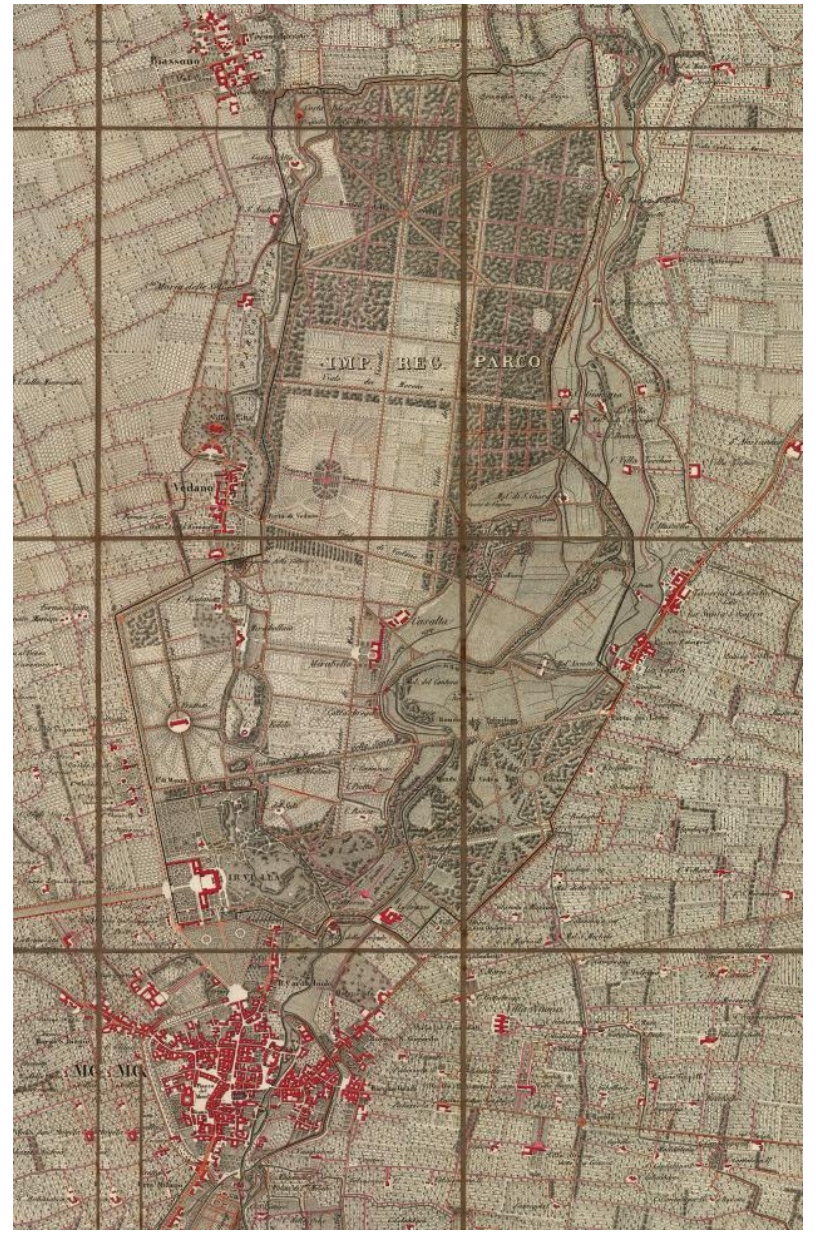

Figure 1. Topography of the city of Monza and of I.R. Villa with corresponding Park and surroundings surveyed on site and draw in the scale of 1:10.000 by the I.R. First Lieutenant

Engineer Geographer Giovanni Brenna, October 1845.

Born in Milan in 1779, Giovanni Brenna studied Mathematics and Drawing, both civil and military. At the young age of 21, he was employed as a draftsman by the Bureau of the French Corps of Engineers during Napoleon's domination of Italy. In 1803, he was then recruited by the Corpo Topografico (Topographic Corps) of the Italian War Office. Promoted to First Lieutenant Engineer Geographer in 1810, Brenna continued working for about 30 years in the Topographic Corps, transformed, after the return of the Austrian in 1814, into the Imperial Regio Istituto Geografico Militare (Imperial Royal Military Geographic Institute) of Austrian High Command. Due to poor health conditions, he left the military career around 1830. Once retired, for the following twenty years (he died in 1854), he continued working as a cartographer, dedicating himself to the project of a 50 sheets-atlas of the area including the city of Milan, the Brianza, the city and lake of Como, and the city of Varese with its pleasant surroundings. Between 1833 and 1851 he published the already-mentioned "Carta Topografica dei Contorni di Milano [...] ", divided into multiple sheets, each of which named after the most significant city in the corresponding area (Milan and its surroundings, Monza, Bollate, Verano, Cantù, Vaprio, Erba, Oggiono, ...). To provide the necessary financial resources for his undertaking, right from the beginning, Brenna looked for subscribers to the maps: those would support the project when it became more and more expensive as the surveying works moved from flat to hilly or 
mountainous areas, longer and harder to be measured and drawn. The advent, in 1840, of the railway between Milan and Monza brought rapid and far-reaching changes in the territory, making it necessary to update some map sheets. Therefore, in 1842 new editions of the Monza and Milan surroundings sheets were published, while the release of the Cantù sheet was postponed because of the railway extension towards Como, and the survey works for the Como sheet remained unfinished. In fact, probably due to funding problems, Brenna's plan remained unfinished compared to the original draft. The Brianza area was completed, though, and is now an extraordinary cartographic tool describing the historic landscape of that territory ${ }^{4}$.

In order to understand Brenna's maps better, it is necessary to know his historical context. Giovanni Brenna lived in a time of great social and cultural innovations. In the field of cartography, those were the years when the first maps were created with scientific and professional methods. He received his professional training in the cartographic school of the French Army, directly related to the important cartographic school of the Cassini family who drew, between 1750 and 1789, the first geometric map (based on geodesic triangulation measurements) of the entire territory of the French Kingdom (the map was published only in 1815). In Italy, the first scientificallysurveyed map was the "Nuova Carta Geografica dello Stato Ecclesiastico" (i.e. New Geographic Map of the State of the Church), commissioned by Pope Benedict XIV, started by the Jesuit priest Roger Boscovich and finalized, after three years of work, by father Christopher Maire in 1755 .

As for Lombardy, Giovanni Brenna's native land, the territory underwent a detailed census of land ownerships during the years of Austrian rule, the so-called "Catasto Teresiano" (i.e. Teresian cadastre), which took place over a period of more than 40 years, between 1718 and 1755. Since the cadastral maps revealed a low level of precision and geometric reliability, the region was surveyed again between the end of $18^{\text {th }}$ Century and the 1830s, using the latest scientific methods. In those years, the Brera Astronomical Observatory, an institution newly founded in Milan by father Boscovich and other Jesuit priests, got involved in the task. Between 1788 and 1791, upon request of the Austrian Government, the Brera astronomers mapped the area surrounding Milan and Mantua, which were then subject to the Austrian Empire. The geodesic triangulation network they developed was subsequently reused, its resolution was improved and its extent was broadened to cover the whole Lombard territory: so the "Carta Topografica del Regno Lombardo Veneto" (i.e. Topographic map of the Kingdom of Lombardy-Venetia) was published in 1833 by the Austrian I.R. Istituto Geografico Militare, the same military corps, to which Giovanni Brenna belonged ${ }^{5}$.

Another crucial map was published around 1830 by the I.R. Istituto Geografico Militare, that is to say, the "Carta dei Contorni di Milano, in quattro fogli fino a 25.000 metri al Nord e al Sud e a 40.000 metri all'Est e all'Ovest" (i.e. Map of Milan surroundigs, in 4 sheets, up to 25.000 meters North and South, and 40.000 meters East and West), to whose drafting Brenna himself probably took part before retiring. That was an innovative edition, because the cartouche and title that traditionally found place in the same area as the map were not

\footnotetext{
${ }^{4}$ For more information about Giovanni Brenna's life and work, see Cazzani, 2009, Donati, 2012 and Viganò, 1983.

${ }^{5}$ Further details about Lombard historical cartography and history of the Lombard landscape can be found in AA.VV., 1984, Bortolotti, 2002 and Negri, 1998.
}

included, while technical data regarding the scale, production and engraver were printed on the map's free outer margin, and the legend of symbols was not even on the same sheet, but was placed on the map container. The map was originally printed divided into 4 sheets, but an alternative edition was published with the map divided into 9 sheets (a format more suitable for commercial use), each of them named after the most significant city of the illustrated area. The "Carta dei Contorni di Milano" was surely a model Brenna turned to while planning his atlas maps (Donati, 2012).

The choice of scale is of particular interest: 1:25.000, large enough to make the size of villa gardens, bridges over rivers or vineyards recognizable. The Brianza territory, characterized by rolling hills and varying landscape, was a uniform system of architectural, landscaping and agricultural interventions; not only isolated and independent monuments, but a single and ordered set, in which villas, service buildings, gardens, treelined paths, woods, agricultural crops, enclosures and hunting lodges were strictly related, and in which aesthetic and productive purposes overlapped in an extraordinary landscape complex (Cazzani, 1994).

The existing cartography so far did not circulate freely and was unfit for lay use; cadastral maps were issued by the Government mostly for fiscal purposes and were only accessible to civil servants. The Teresian cadastre, despite being a geometric particle cadastre and having a low level of geometric accuracy, provided somehow a representation of the territory: buildings, cadastral parcels and corresponding map numbers were indicated, and each individual parcel was hatched and coloured to show different crops, roads, rows, gardens, etc. Interestingly, subsequent $19^{\text {th }}$ Century Lombard cadastral maps did not directly represent the territory but only showed the property borders and scant physical elements: in order to be interpreted, they required related "sommarioni" (registers) that reported more detailed information corresponding to each parcel.

Hence the exceptional importance of Giovanni Brenna's map. His survey returns an accurate territory representation, which soon proved to be essential for the perception of the variegated Brianza region and its configuration, of which, at the time, there were only general notions. This is particularly important considering the historical moment, characterized by Lombard society rapidly transforming and beginning to invest in industries and infrastructures: the local knowledge was for them a key-element for programming choices and investments.

Through appropriate symbols specified in its legend, Brenna's topographic map shows the land chorography, main and secondary watercourses (rivers, artificial canals, irrigation ditches ...), the road network with its classification (roads accessible to vehicles, tree-lined streets, pedestrian paths ...), bridges and railways. The map shows municipality boundaries, and meticulously reports, for each urban center, single buildings and the most relevant site designations; in the case of religious buildings, if they represent multi-parish headquarters, a parish see, or a simple prayer oratory. As for parks and gardens, the map returns the precise drawing of their compositional plans. Also the agricultural land is carefully described, showing parcel partitions, different cultivation types (fields, vineyards, rice fields, vegetable gardens, meadows, woods, ...), the widespread presence of farmhouses, villas and aulic buildings (casini particolari), and the dense network of local and service roads connecting them. The location of cemeteries, that Napoleonic rules had moved out of urban centers, is also indicated. Lastly, the map indicates the presence of other urban and rural landscape components, such as enclosures (serragli), bird snares (roccoli); different types of industrial activities as brick kilns (fornaci), spinning mills (filande) and mills (mulini); and 


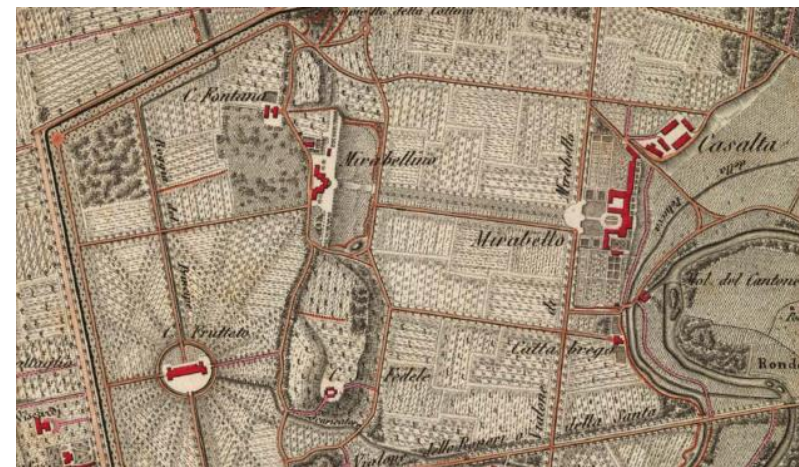

Figure 2. Extract from the Brenna's map of the Royal Park of Monza: it should be noted the abundance and precision of graphic details and denominations used to describe the territory's landscape and architectural characteristics.

all those infrastructural elements that prove how much the Lombard landscape was shaped by human hand, and became urbanised, for example land springs (fontanili), irrigation ditches (rogge), piers (darsene) and terracing (terrazzamenti) (Frigerio et al., 2010).

The level of detail and clarity of his survey of landscape compositional elements makes of the Brenna's map a precise and extremely valuable reference for the reading and studying of historic landscape and garden evolution (Figure 2).

For a few specific sites, Brenna provided map enlargements in order to provide better representation of the different components and their relationships with surrounding areas. Besides the extraordinary 1:3000 enlargement of Villa Tittoni site in Desio, it is essential to mention the "Topografia della Città di Monza e I.R. Villa col rispettivo Parco e d'intorni rilevata d'in sul terreno e disegnata nella proporzione di 1 a 10.000 dall'I.R. Primo Tenente Ingegnere Geografo Giovanni Brenna, ottobre 1845" (i.e. Topography of the city of Monza and of Imperial Royal Villa with relative Park and surroundings surveyed on site and drawn in the proportion of 1:10.000 by the Imperial Royal First Lieutenant Engineer Geographer Giovanni Brenna, October 1845), unsurpassed photography of the Monza Royal Villa and its park (Figure 1). This map also had good success among traders and tourists, as it became frequently used by Milanese citizens who would plan, thanks to the recently built railway, little journeys to the nearby city of Monza, the doorway to the green Brianza.

Although Brenna is neither a garden designer nor a landscape architect, but a topographer, his awareness and acuity in depicting the features of the area around Milan and Brianza, makes him a very interesting personality, who was able to describe, with great sensitivity and understanding, the landscape and architectural characters of his region.

\section{FROM HISTORIC MAPS TO LANDSCAPE AND BUILT HERITAGE PRESERVATION, AND DESIGN PROPOSALS}

To define an active preservation and management plan about built and landscape heritage it is necessary to know the complexity of the site; this requires both direct knowledge from onsite surveys and visits, and indirect knowledge from documentation. Of course, the method used to read and analyze built and landscape heritage is directly linked to the purpose of the analysis. The targets underlie the methods selected, while the documents useful for the analysis and interpretation of the collected information form the basis for creating preservation and design projects. The European Landscape Convention recommends that landscapes to be identified and assessed, should not simply be subjected to judgment, but their features need be described with a view to undertaking projects. The purpose is to highlight multiple, widespread values and potentialities and to define the actions that each site requires in order to ensure widespread landscape quality. The actions might not only be about conservation, but also about regenerating degraded areas or involve substantial innovation (European Landscape Convention, 2000).

The case study considered here is the Royal Park of Monza; the purpose of the study is to read and evaluate built and landscape heritage typologies and features involving historic, perceptive and constructive components, and to investigate - comparing old and current maps - the historic stratification.

Located north of the city of Monza, and northeast of the Royal Villa, the Royal Park of Monza (688 hectares) is the biggest fenced park in Europe. Requested by Eugène de Beauharnais, Viceroy of Italy, the park was designed, between 1806 and 1808, by the architect Luigi Canonica to extend the already existing Giardini Reali, the English garden of the Royal Villa, and to create a model country estate and a large game preserve for the hunting entertainment of the Viceroy and his court. Architect Canonica expanded the initial complex embedding the $17^{\text {th }}$ Century villas of Counts Durini (Villa Mirabello and Villa Mirabellino) with annexed formal gardens, many farmhouses and mills, an extensive area of woodland and a large stretch of the river Lambro. $19^{\text {th }}$ Century cartographic sources shows how the central part of the park was intended, since the beginning, for agricultural production, thanks to the presence of meadows, rye, corn and wheat fields irrigated with a rich network of artificial canals and ditches, fed by natural springs or by the river. Maps also reveal that there were woodland areas to the north and along the eastern rim, tree-lined avenues and vegetation architectures around buildings (formal gardens, a geometric designed orchard, ...) or in support of the hunting entertainment (bird snare, pheasantry, ...). An extended network of avenues crossed the park, connecting the most important buildings and providing perspective views on historic architectures or the surrounding landscape. Open to the public since 1919 , in the first half of the $20^{\text {th }}$ Century the park went through a period of changes and neglect. In the northern section, the most severely modified area of the park, a big part of the woodland was removed to build, in 1922, the renowned Autodrome, and in 1929 an exclusive golf course, still in business. In the central part, fields were replaced for some years by an Hyppodrome, and most of the buildings were abandoned and even now are no longer used. The southern part, with the Royal Villa and its garden, is still the best preserved area. ${ }^{6}$ Nowadays, the park is a very popular venue, used every day by both the population of neighbouring municipalities and by tourists as a leisurely destination in the weekends or during events organised by associations active in the park.

At present, the park displays several conservation problems: the context is profoundly changed from a past agricultural and natural landscape, to the current urban and peri-urban landscape of the city of Milan; the agricultural and wood areas of the park are reduced and simplified; different transformations of the settlements have canceled important historic features, some current uses are incompatible with historic components, many buildings are abandoned or under-utilized, and the present maintenance level is too low, to make the complexity and the

\footnotetext{
${ }^{6}$ For more information about the Monza Royal Park history, see De
} Giacomi, 1989, Mezzanotte, 1830 and Rosa, 2009. 


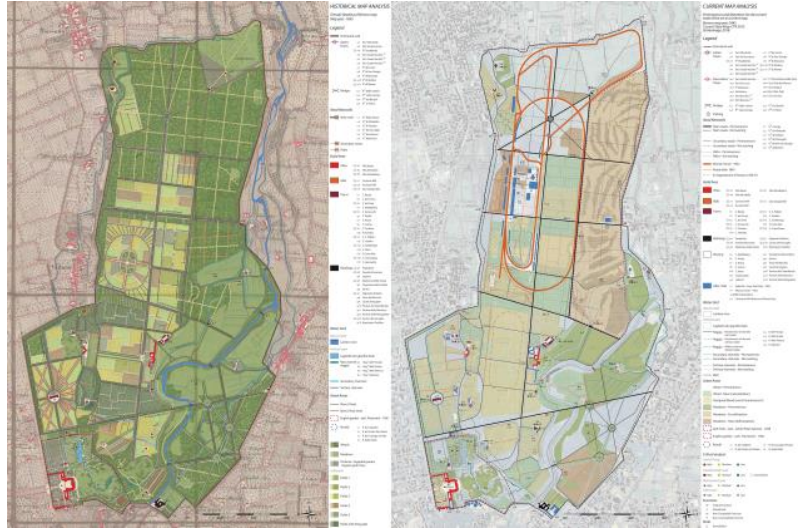

Figure 3. Royal Park of Monza case study: accurate reading and analysis of Brenna's map (left) and comparison with current situation (right), pointing out the level of decay, transformation, maintenance and functions permanence.

peculiarities of this important site clearly readable. The georeferenced Giovanni Brenna's map was considered the main reference to understand the complexity of Royal Park of Monza and its context: the accurate and detailed representation, abundance and precision of details and number of toponyms reported in the map, made it possible to underline and recognize the historic structural elements and functions of the site. Specifically, it was possible to identify buildings (villas, rural buildings, mills, doors and gates, other buildings, wall), road networks (main roads, secondary roads, paths), water networks divided into natural water (Lambro River) and artificial water (lake, main canals called roggia, secondary canals), agricultural areas and vegetation (cultivated fields, fields with vineyard, meadows, wood, hunting wood, formal garden, orchards, row of trees, isolated trees) and to compare all these elements with the current situation, recognizing the level of permanence or transformation of the different areas, components and features of the park. The direct survey was necessary to value the conservation grade, identifying the level of decay, transformation, maintenance and the functions (distinguished as original function, new compatible function, new incompatible function, abandoned) as illustrated by the Figure 3 .

Comparing the situation documented in Giovanni Brenna's map with the current status it was possible to evaluate the Royal Park of Monza elaborating a SWOT analysis, involving cultural-architectural, landscape-ecological, social and economical aspects, identifying values, critical areas, potentialities in order to delineate a preservation and management strategy (Pereira Roders et al., 2019).

It is important to remember that built and landscape heritage is a complex system consisting of elements in relation to each other and to the users: it is an expression of cultural identity that it is necessary to consider while defining a master plan focused on the definition of new compatible plans and uses, identifying the ways to mitigate alteration impacts, requalify degraded areas, enhance natural, historic and cultural values, improve documentary and educational options, manage new projects and opportunities, looking at social needs and functional options.

The study of the Royal Park of Monza has demonstrated that many built and landscape heritage components documented by Giovanni Brenna are disappeared or hidden like the heterogeneous cultivation structures, the hunting wood settlement, the complex water and road network. The site lost textures and features that can be re-discovered and re-designed to valorize the old traces, and to create a new composite landscape, involving and linking cultural, natural, urban and peri-urban aspects (Figure 4). This research has shown how the use of archival and documentary sources and in particular of historical maps, as well as detailed surveys, is a fundamental condition for approaching a new project in a conscious way, but also for promoting and making known to the public the values and characters of the past that have now been erased or hidden. They could be emphasized with a new project aimed at preserving and enhancing the past, but they can at least be disclosed, through new communication tools.
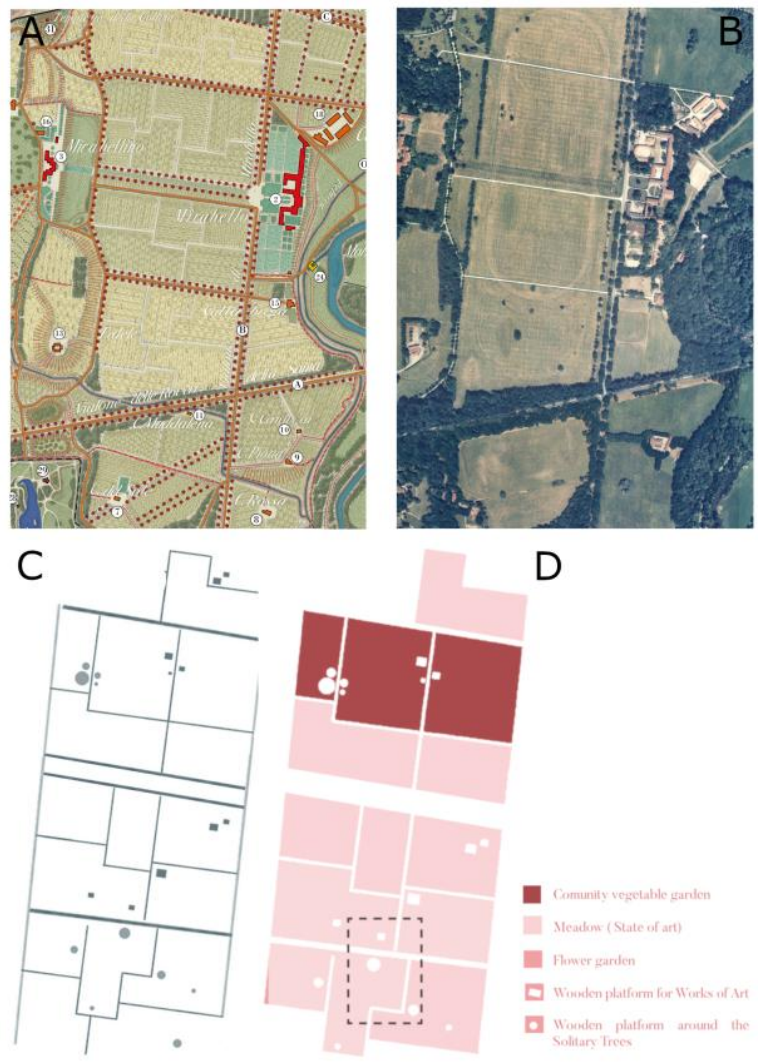

D
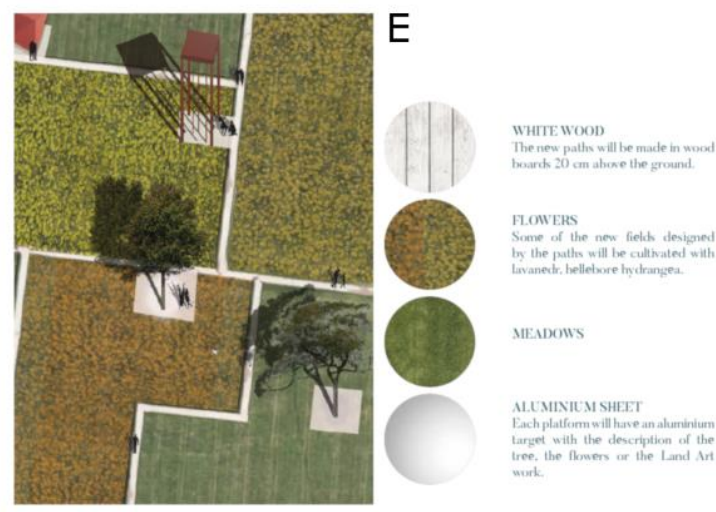

Figure 4. Master Plan proposal for the Royal Park of Monza: Brenna's map (A) shows the clear presence of different types of crops, paths and water network, while the current aerial view (B) shows mostly meadows. The project wants to re-discover old, often hidden, traces and use them to re-create a new landscape: the old fields drawing is re-created with wood paths; each sector is filled with flowers and vegetable gardens (C-D). Where paths cross a tree or a land art installation, it becomes an exhibition platform or rest area $(\mathrm{E})$. 
In order to promote the cultural and local identity and to involve people in heritage preservation it may also be useful to develop apps and innovative tools capable to make the complexity and the richness of our past clear.

\section{APPS TO PROMOTE CULTURAL IDENTITY TOWARD A PROACTIVE DIMENSION}

Nowadays, the added value of the historic cartography in supporting research and analysis of the built environment in support of planning preservation actions is progressively recognized together with the growing of services and tools based on Open Data access to historical information for landscape analysis (Brumana, 2013). The availability of historical maps is increasing. The digitization of map collections by the Archives Bodies in Italy has been massively undertaken, as in the case of the National Archive of Milan that is progressively acquiring and publishing the maps, once digitalized, including the Brenna's Map here considered: it is the case of the web site 'Atlante dei Catasti Storici e delle Carte Topografiche della Lombardia' (i.e. Atlas of the Historical Cadastres and Topographic maps of the Lombardy Region); through the DIVENIRE application it allows users to access the maps owned and conserved by the Archive, even if it is limited to the visualization, without georeferentiation and with no chart acquisition. Or across Europe as well: it is the case of theMaps data (WMTS-Web Map Tiled Services), created in a collaboration between different institutes, among which the Austrian State Archives, owner of the first and second military surveys drawing a picture of Europe in the $19^{\text {th }}$ Century.

Digitisation, georeferencing and development of the software to visualise the maps on different systems have been also increasing. The availability of different data sources, as in the case of historical maps, requires nowadays to exploit services to reduce the time of discovery and accessing such data, to maximizing the benefits of a massive use of them by the different users with a positive impact on heritage preservation.

A brokered Virtual Hub approach for the generation of web applications based on historical maps has been experimented (Previtali, 2018): an application (GEOPAN ATL@S APP) was developed to manage different historical maps (national, regional and urban maps) across Eu. It is based on a Virtual Hub adopted to publish historical maps as Open Data (Mazzetti, 2017): a hub works like the applications we use to access when we search and book flights or hotels, merging all the available data coming from the different proprietary sources of data.

The GEOPAN APP allows to perform semantic searches based on temporal and spatial subsetting, thanks to the linked endpoints of the Open Data without any duplication and with real time updating. The GEOPAN APP can be progressively implemented by new data sets: in this case different historical maps georeferenced in the area of the Park are available together with the Brenna Map, among which the Military Map (Carta Militare del Lombardo-Veneto) and the three historical cadasters (Catasto Teresiano, Catasto Lombardo-Veneto and Cessato Catasto), as illustrated by the Figure 5. The possibility to access the multi-temporal data published, allows the users to find the different published historical cartographies in the different periods, to read and highlight the transformations, permanencies and mutations respect the current state of the art through their comparison with the current map layers (i.e. Satellite Imagery, Urban Technical Map, Open Street Maps (OSM), UAV Orthophotos).

Innovative tools covering the entire process, from the
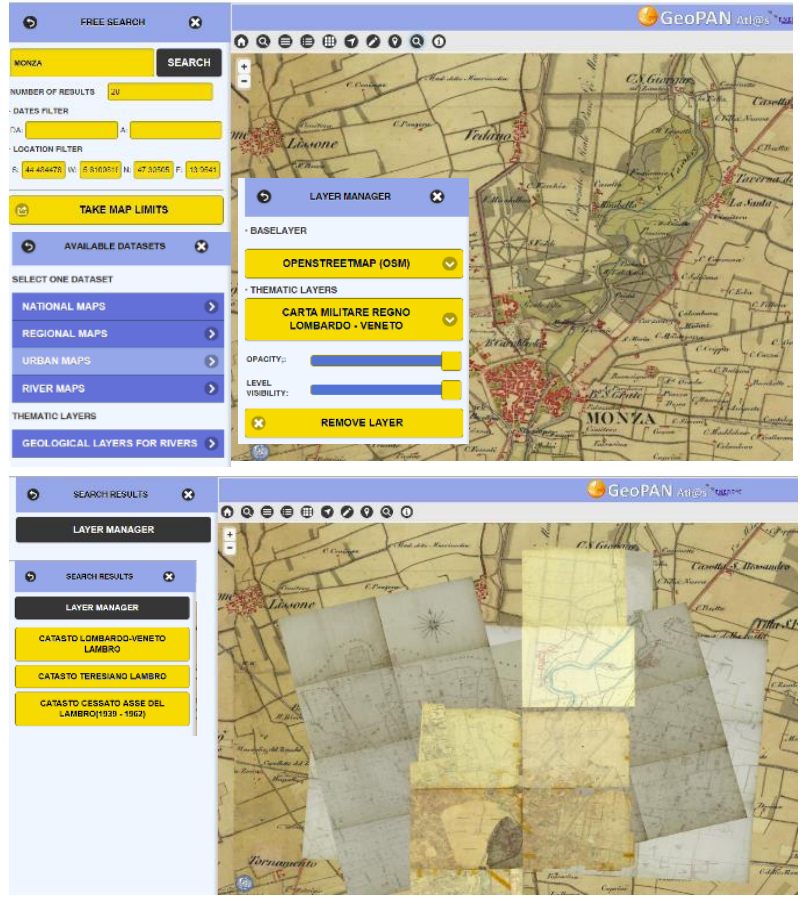

Figure 5. The map search query service supported by the GEOPAN APP. A sample of the georeferenced maps nowadays available on the area selected: the Military Map (Carta Militare

del Lombardo-Veneto) and the three historical cadasters

(Catasto Teresiano, Catasto Lombardo-Veneto and Cessato Catasto).

acquisition to the publishing, are offered by the GEOPAN APP, as the map registry, open source webGIS data management, and Hub integration, in order to support the critical analysis of the maps, the representation of the historic stratification, the evaluation of the conservation level, the definition of heritage reuse and management.

The development of applications and tools contributing to promote the cultural and local identity needs to be progressively tuned from passive to proactive services in order to better involve planners and citizens in heritage preservation: the vector based digitization of the Brenna's Map, highlighting the layers upper described, is aimed to rise in this direction the reading of the historical maps by the citizens and professionals. The aim is to show how to recognize - thanks also to innovative tools and APP - the historic and cultural significance of our built and landscape heritage and also to consider it like a current urban, architectural, landscape, and social resource. The historic complexity of built and landscape heritage and the level of permanence are recognizable and evaluable comparing multitemporal historic and current maps and surveying the current situation in order to define preservation strategies.

The bet for the future is to transform the APP toward an instrument of awareness, rising with strong pro-active capacity to forge new generation of design plans able to take into account the cultural identity of the places aiming to rediscover the traces of the past; the systematic use of historical maps within the on coming planning and decision making can have an important role within the entire cycle of the Park heritage preservation, from the analysis till to the actions.

The Lombardy Region is launching a Master Plan Tender on the Park, and it is including the access to such data sets, as in the case of the Brenna Map.

At the same time, the APP is also addressed to the fruition by a 
large public of non-expert users (tourists, citizens, bikers, students) supporting the access to the extraordinary richness of the historical map heritage contents. Navigation itineraries performed across the rich landscapes and built environment of the Royal Park of Monza have been studied and proposed by the students of the Preservation Studio course. They can be uploaded on the GEOPAN APP and they can be integrated by the design ideas developed during the course. The objective is to foster the large public to choose itineraries of biking or walking across the time, across subjects dense of permanences, still readable, spanning from the 'water' theme, the anthropic canalizations (with the primary order represented by the 'Roggias' and secondary rich network order) derived from the Lambro river to harvest the cultivation areas, or addressed to feeding the mills presents in the Park, to the road and path network described, till to the ancient cultivated parcels traces, progressively disappeared, that can be re-discovered by the design ideas. Edit tools connected to the geolocation system allow the students, or APP users, to sketch itineraries on site or offsite, saving and exporting them within open source or proprietary GIS tools, or to share them among the visitors (Figure 6). Itinerary maps designed by the students is an outcome that allows citizen to appreciate the multi-temporal fruition of the Park choosing among different thematic itinerary subjects (Figure 7). Virtual museums developed on the built environment can be fed up via multi-temporal geodata hub, exploiting more informed narratives and immersive experiences transferring contents of the past (Brumana, 2018).

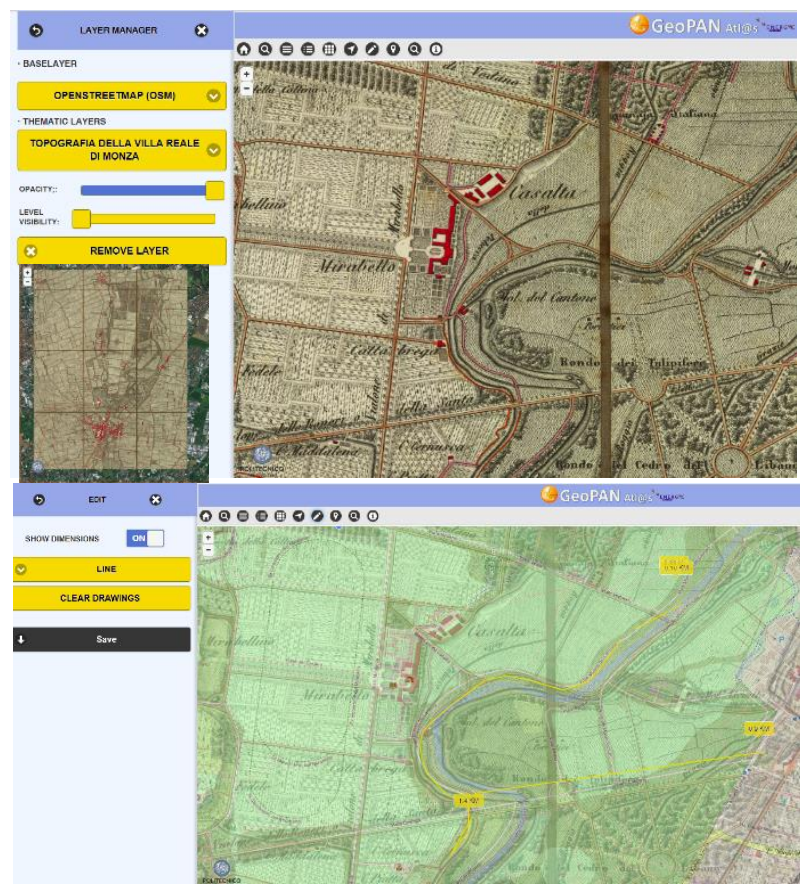

Figure 6. The navigation of the Brenna's Map and the comparison with the current state of the art (Open Street Map), through the transparency percentage. A sample of the edit tool supporting itinerary map that can be sketched on-or off-site.

The semantic based search tool allows to perform queries across Europe without borders, by integrating keywords within the metadata description supporting the Hub data management referenced to the historical or current open data linked to the hub. Just to make an example, the word HUL (Urban Heritage Landscape) can be used to tag different on developing cases (the Case of the Monza Royal Park together with the on going

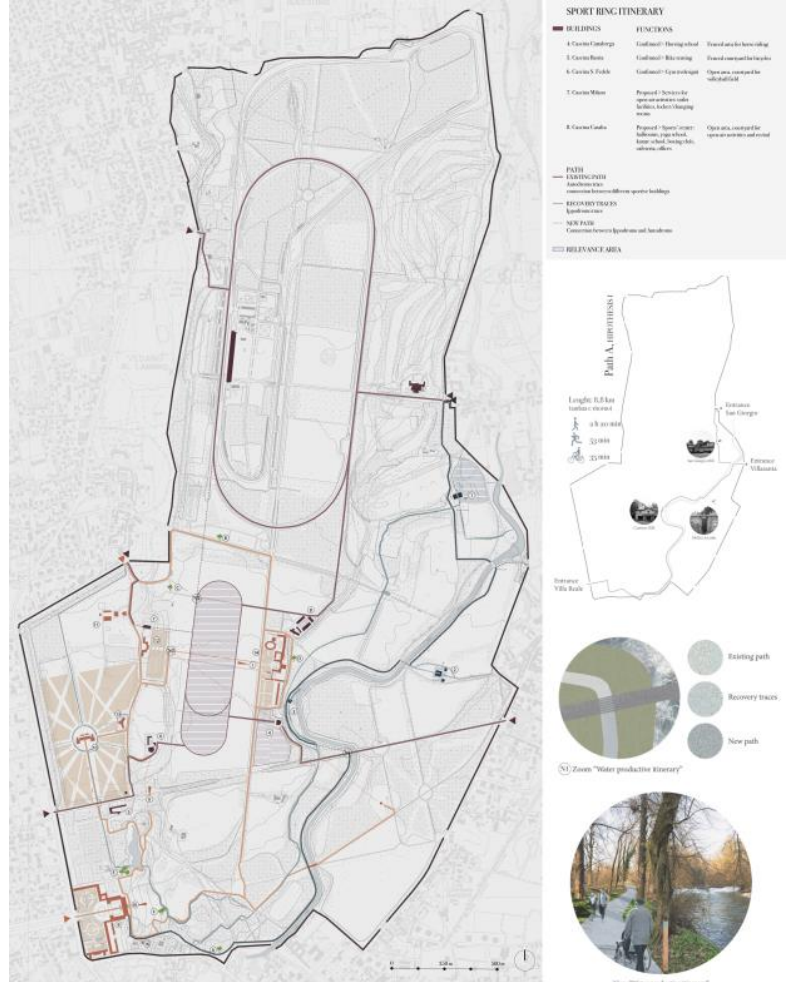

Figure 7. Royal Park of Monza Itinerary map proposal: a sport ring pedestrian and bicycle itinerary, that connects several buildings currently existing in the park and makes readable traces from the past, documented by Giovanni Brenna's map

The trails are built in calcestre (stabilized gravel), in three different shades of grey to differentiate existing (racetrack), recovery (old hippodrome) and new paths.

case of the City of Strasburg that is carrying out an interesting Heritage\&Development strategy, connecting the new planning of the 'Deaux Rives' to the historical maps): once tagged with the keyword both this cases can be brokered and discovered and accessed by the GEOPAN APP users in the world, together many others samples that could be added in the future: the objective is to make available best practices and case studies to enhance the heritage preservation within the planning activities and within the tourists and citizen making them aware of the richness a past still readable helping to undertake new cases.

\section{CONCLUSIONS}

The research presented in the paper tests how to recognize the historic and cultural significance of our built and landscape heritage - using historic maps and particularly the Giovanni Brenna's map - and also to consider it like a current urban, architectural, natural, social resource.

It is necessary now to create awareness among citizens, administrations and professionals of the importance of historic stratification before designing a new building/urban plan.

In this regard, it is important to take into account that historical sources (documents, maps, surveys) are the main reference for restoration and conservation projects, but are often not considered enough in urban planning and new design projects. The same historical sources are often not known and understood by the public and specifically they are not identified. The development of innovative tools and app will connect the public to the past in an interactive way making the same public more interested in the design and planning process participation and 
more aware of the value of the past.

According to the UNESCO Recommendation, now is the time to develop strategies for historic urban landscape management.

\section{ACKNOWLEDGEMENTS}

The research leading to the results of this paper is partially funded under the ICT Policy Support Programme (ICT PSP) as part of the Competitiveness and Innovation Framework Programme by the European Community (CIP) GA n ${ }^{\circ} 620400$. The authors would also thank the following Assistant Professors for researches carried out the within the ENERGIC-OD funded project (Polimi partner Sc. Res. R. Brumana): Dr. Arch. Daniela Oreni for the georeferentiation of the historical cadastres of the case study area and Dr. Ing. Mattia Previtali for the. georeferentiation of the Brenna's map and the Military Map and for the Geopan APP implementation The research described here has been tested and developed within the Architectural Preservation Studio of the Laurea Magistrale (M.Sc.) degree in Architecture (Architecture - Built Environment - Interiors Programme) - Politecnico di Milano, Prof. Alberta Cazzani and Prof. Raffaella Brumana with Arch. Carlotta Maria Zerbi PhD, Arch. Sara Caspani and Arch. Anna Turrina during the academic years 2017/2018 and 2018/2019, involving over 100 students. Specifically the plans attached here were elaborated by: Ebrahim Abnar, Caterina Cameli, Melis Drogul, Monica Ferraboschi, Ilaria Furbetta, Du Jian, Zhao Jingxuan, Wang Mengwai, Luca Rizzo, Alberto Roncelli and Chiara Tassinari.

\section{REFERENCES}

AA.VV., 1984. L'immagine interessata. Territorio e cartografia in Lombardia tra 500 e 800, Archivio di Stato di Milano, Nodo Edizioni, Como.

Archivio di Stato di Milano (http://asmilano.it/Divenire/home .html) (Accessed 12.03.2019).

Boriani, M. \& Cazzani, A., 2014. Cultural Heritage Preservation in Italy, in Casnati, G., The Politecnico di Milano in Armenia, Oemme Edizioni, Venezia, 33-42.

Bortolotti, L., 2002. Storia, città, territorio, Franco Angeli Edizioni, Milano.

Brumana, R., Oreni, D., Cuca, B., Rampini, A., Pepe, M., 2013. Open access to historical information for landscape analysis in an SDI framework, International Journal of Agricultural and Environmental Information Systems, 4 (3), 18-40. IGI Global, https://doi.org/10.4018/ijaeis.2013070102, ISSN: 19473192.

Brumana, R., Oreni, D., Caspani, S., Previtali, M., 2018. Virtual museums and built environment: Narratives and immersive experience via multi-temporal geodata hub, Virtual Archaeology Review, 9 (19), 34-49. (https://doi.org/10.4995 /var.2018.9918).

Cazzani, A., 1994. Il paesaggio delle grandi residenze briantee nei documenti cartografici e iconografici tra XVIII e XIX secolo: problemi di tutela e conservazione, in I giardini del Principe, Atti del IV Convegno Internazionale - Parchi e giardini storici, parchi letterari, Racconigi, 603-612.

Cazzani, A., 2009. Brenna Giovanni, in Cazzato, V., Atlante del Giardino Italiano 1750-1940. Dizionario biografico di architetti, giardinieri, botanici, committenti, letterati e altri protagonisti. Italia Settentrionale, Istituto Poligrafico e Zecca dello Stato, Roma, 225-226.

De Giacomi, F., 1989. Il Parco Reale di Monza, Associazione Pro Monza, Monza.

De la Torre, M., 2002. Assessing the Values of Cultural Heritage: Research Report, The Getty Conservation Institute.

Donati, M., 2012. Storie di Imprenditoria Lombarda. Giovanni Brenna, cartografo di Lombardia, Associazione Culturale Casimiro Teja, Eventi s.a.s, Cesano Maderno.

Frigerio, F., Mappelli, L. \& Viscardi, L., 2010. Il paesaggio agrario canturino: indicazioni per la salvaguardia e la valorizzazione", Tesi di Laurea in Progettazione dell'Architettura Sostenibile, Facoltà di Architettura e Società, Politecnico di Milano, Relatore Lionella Scazzosi.

GEOPAN atl@s APP http://geoserver.atlas.polimi.it/examples/ servlets/Geopan/D/Entry/selector2b.html

(Accessed 12.03.2019).

'Mapire - Historical Maps Online' geoportal (https://mapire.eu/en/) (Accessed 12.03.2019).

Mazzetti, P., Latre, M. Á., Ernst, J., Brumana, R., Brauman, S., \& Nativi, S., 2015. Virtual hubs for facilitating access to open data, in EGU General Assembly Conference (Vol. 17).

Mezzanotte, G., 1830. L'Imperial Regio Parco presso Monza, Monza.

Negri, G., 1998. Comprendere il paesaggio: studi sulla pianura lombarda, Electa, Milano.

Pereira Roders, A. \& Bandarin, F., 2019. Reshaping Urban Conservation. The Historic Urban Landscape Approach in Action, Springer Nature Singapore Pte Ltd.

Petzet, M., 2004. Principles of preservation: an introduction to the International Charters for Conservation and Restoration 40 years after the Venice Charter, in AA.VV., International Charters for Conservation and Restoration. Monuments \& Sites, I. ICOMOS, München, 7-29.

Previtali, M. \& Latre, M.Á., 2018. A brokered Virtual Hub approach for the generation of web applications based on historical maps, Appl Geomat (2018) 10: 453. (https://doi.org/10.1007/s12518-018-0235-1, 453-472).

Recommendation on the Historic Urban Landscape, 2011. UNESCO, Paris (https://whc.unesco.org/uploads/activities/ documents/activity-638-98.pdf).

Rosa, M., 2009. La Villa, i Giardini e il Parco di Monza nel fondo disegni delle Residenze Reali Lombarde, Skira.

Sonkoly, G.., 2017. Historical Urban Landscape, Palgrave Macmillan.

European Landscape Convention, 2000, Florence, Italy (https://rm.coe.int/1680080621).

Viganò, A., 1983. Per una cartografia briantea: l'opera di Giovanni Brenna, in I quaderni della Brianza, anno VI, 30. 